\title{
Double trouble: Description of an attack on a nesting Delta sp. (Vespidae) by two Stilbum cyanurum (Chrysididae) cuckoo wasps
}

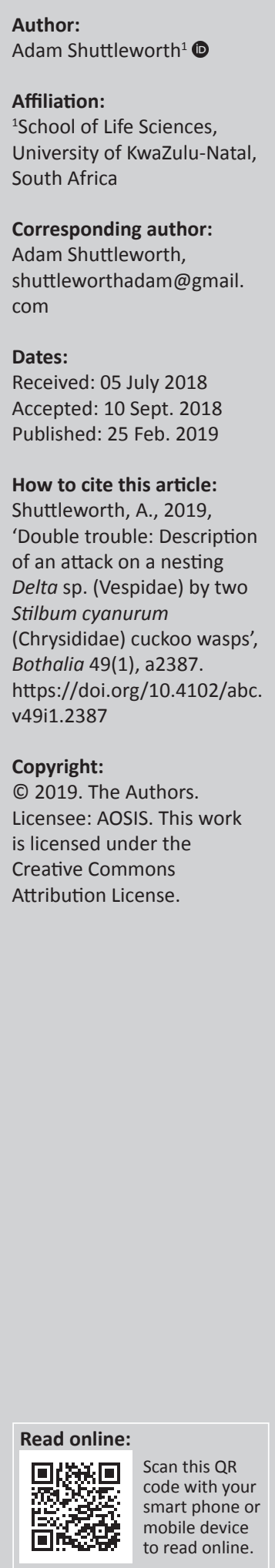

Cuckoo wasps (Chrysididae) are well known for their habit of laying eggs in other insects' nests, but the strategies by which they sneak their eggs into hosts' nests have seldom been described. I report observations of an attack by two Stilbum cyanurum (Chrysididae) individuals on a nesting Delta sp. (Vespidae: Eumeninae). The attack lasted over $1 \mathrm{~h} 30$ min and involved both $S$. cyanurum wasps simultaneously mobbing the Delta $\mathrm{sp}$. in attempts to gain access to her nest. The mode of attack and oviposition are described, and details are compared with observations of attacks by $S$. cyanurum in other parts of its range.

\section{Introduction}

Cuckoo wasps (Hymenoptera: Chrysididae) are well known for their parasitic (and typically cleptoparasitic) life history, in which, like the eponymous avian cuckoos, eggs are laid into the nests of other insects. The developing cuckoo wasp larva then consumes the host's eggs or larva and the provisions laid down for the host larva (Gess \& Gess 2014). Hosts are mainly aculeate Hymenoptera for members of the subfamily Chrysidinae, but also include sawflies, moths or stick insects for members of the subfamilies Amiseginae, Loboscelidinae and Cleptinae (Kimsey \& Bohart 1990). Hosts are well established for many species, but these have mainly been deduced from the collection of cuckoo wasps emerging from the nests of other insects (Gess \& Gess 2014; Kimsey \& Bohart 1990). Although cuckoo wasps are often observed around the nests of potential hosts, the strategies used to sneak their eggs into the nests of other insects remain poorly known, and direct observations of oviposition have seldom been reported.

In some cuckoo wasp species, the female oviposits on the prey insects of her host species and the eggs are then inadvertently transported back to the host nest inside the prey items which are being laid down as provisions for the host's own larva. This strategy has been established for Pseudolopyga taylori (Bodenstein) and Omalus biaccinctus (Buysson) (both Chrysididae), which oviposit, respectively, on Nysius raphanus Howard (Lygaeidae) bugs or Macrosiphum euphorbiae (Thomas) and Myzus persicae Blackman (both Aphididae) aphids (José, Carrillo \& Caltagirone 1970; Winterhagen 2015). This strategy is also suspected for Holopyga generosa (Förster) (Chrysididae), which has been found to oviposit on Palomena prasina Linnaeus (Pentatomidae) bugs (Veenendaal 2012). A different mechanism relying on chemical crypsis has been described for Hedychrum rutilans Dahlbom (Chrysididae). This species mimics the cuticular compounds of its host, Philanthus triangulum (Fabricius) (Crabronidae), to avoid detection within the host nest (Strohm et al. 2008). These mechanisms avoid confrontation with host species, but this may not be the case for all cuckoo wasps. Most chrysidids (particularly in the subfamily Chrysidinae) have a highly sclerotised integument and a concave abdomen which allows individuals to roll into a ball. This is assumed to offer protection from attacks by angry hosts, and suggests a degree of confrontation in the mechanisms of oviposition into host's nests for most species (Kimsey \& Bohart 1990). Deliberate attacks on the adult hosts, however, have seldom been reported. Here I describe an opportunistic observation of an attack on a nesting Delta sp. (Vespidae: Eumeninae) by two Stilbum cyanurum (Förster) (Chrysididae: Chrysidinae) individuals.

Stilbum cyanurum has a wide distribution throughout the warmer parts of the Old World (Kimsey \& Bohart 1990). Hosts of this species are quite varied across its range and include species of Afreumenes Lepeletier, Delta de Saussure, Eumenes Letreille, Pseudabispa van der Vecht (all Vespidae: 
Eumeninae), Megachile Latreille (Megachilidae) and Sceliphron Klug (Sphecidae) (Berland \& Bernard 1938 cited in Gess \& Gess 2014; Kimsey \& Bohart 1990; Matthews \& Matthews 2009; Móczár 1961; Weaving 1995). Although phylogenetically diverse, these hosts all exhibit similar nest architecture (Kimsey \& Bohart 1990). In South Africa, this species has been reported to use species of Delta and Afreumenes as hosts (Gess \& Gess 2014; Weaving 1995).
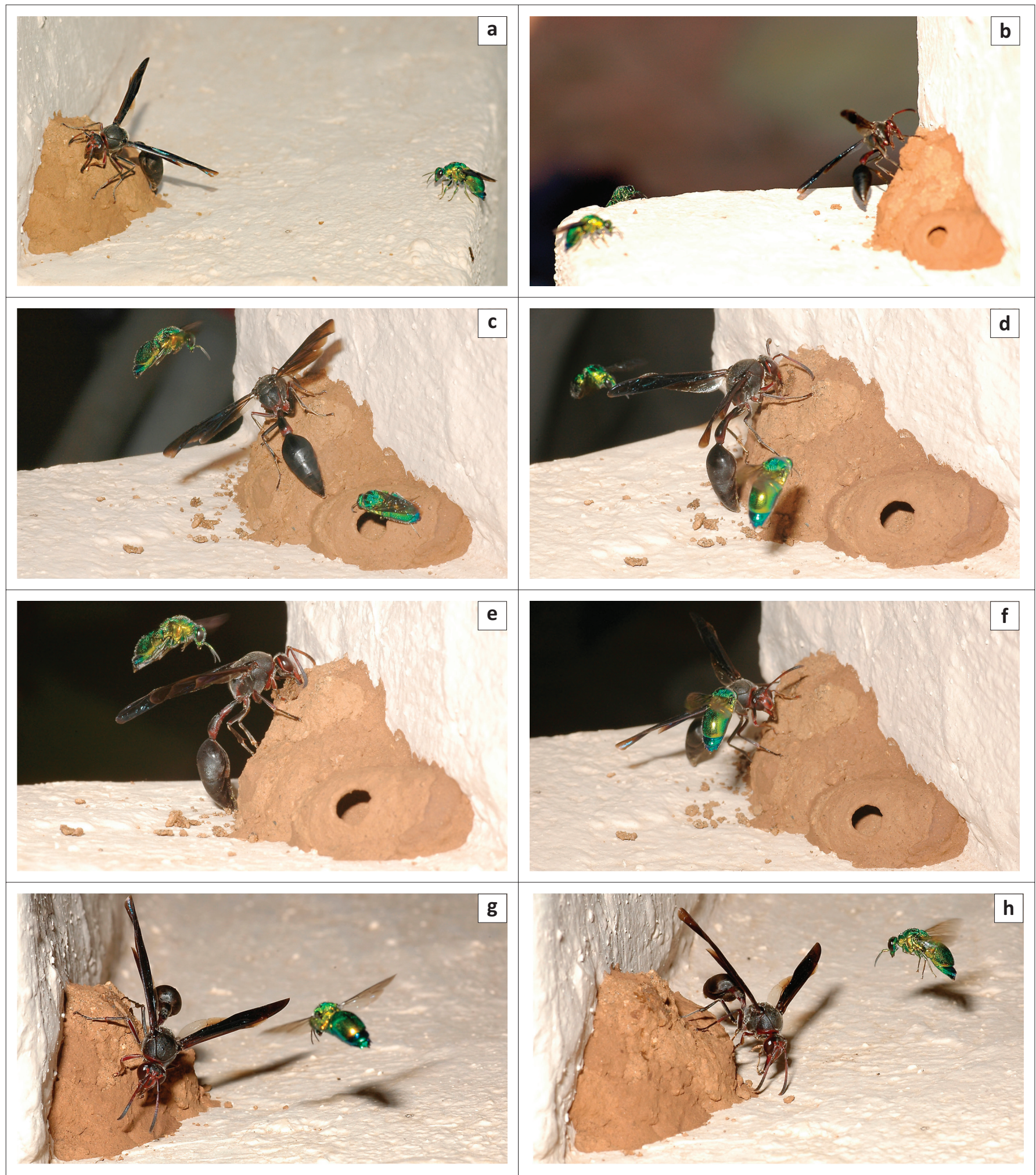

Source: Photos courtesy of the author, Adam Shuttleworth

FIGURE 1: Nesting Delta sp. (Vespidae: Eumeninae) being attacked by two Stilbum cyanurum (Chrysididae) individuals. In between bouts of mobbing, the two S. cyanurum wasps would perch on the wall close to the nest (a)-(b). During bouts of mobbing, the two $S$. cyanurum wasps would simultaneously attack the Delta sp. from the air actively harassing and dive-bombing her (c)-(h). The Delta sp. exhibited defensive behaviour, quivering her wings and facing her attackers, and would periodically fly at the mobbing $S$. cyanurum wasps (i) colliding with them in the air (j). 


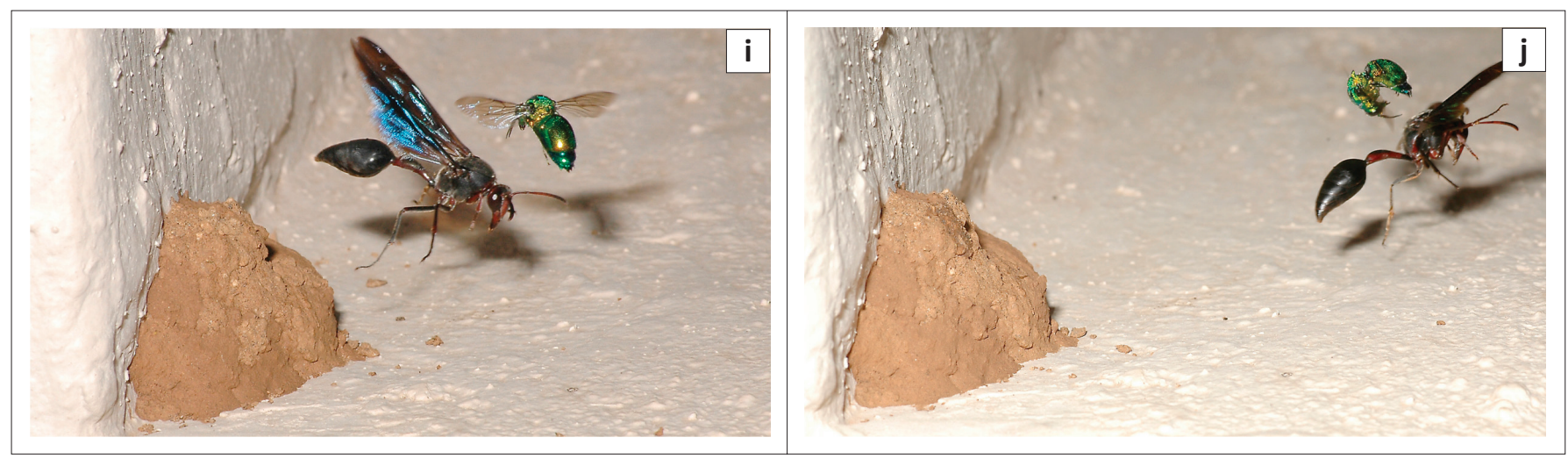

FIGURE 1 (Continues...): Nesting Delta sp. (Vespidae: Eumeninae) being attacked by two Stilbum cyanurum (Chrysididae) individuals. In between bouts of mobbing, the two S. cyanurum wasps would perch on the wall close to the nest (a)-(b). During bouts of mobbing, the two $S$. cyanurum wasps would simultaneously attack the Delta sp. from the air, actively harassing and dive-bombing her (c)-(h). The Delta sp. exhibited defensive behaviour, quivering her wings and facing her attackers, and would periodically fly at the mobbing S. cyanurum wasps (i) colliding with them in the air (j).

\section{Research methods}

The attack reported here took place at the lodge of Balule Private Game Reserve on 30 November 2008. This site is approximately $21 \mathrm{~km}$ north of Hoedspruit, Limpopo province, South Africa (coordinates and altitude: $24^{\circ} 09^{\prime} 21.18^{\prime \prime}$; $30^{\circ} 57^{\prime} 16.62^{\prime \prime}$ E. 354 metres above sea level). The lodge is situated on the banks of the Oliphants River in lowveld savannah. A Delta sp. wasp had built a nest on the steps leading up to the lodge patio. During the course of the morning, it was noticed that the Delta sp. was active on the nest and at approximately noon, two cuckoo wasps (subsequently identified as S. cyanurum) were observed close to the nest. I observed (and photographed) the behaviour of the cuckoo wasps from 12:30 to 12:47 and again from 14:00 to 14:14. Photographs were taken with a Nikon D70s digital SLR camera fitted with a Tamron DiII $90 \mathrm{~mm}$ macro lens. I did not have permits to collect insects so I was unable to collect voucher specimens. Wasps were identified from photographs by Professor Denis Brothers (University of KwaZulu-Natal, Pietermaritzburg).

\section{Ethical considerations}

No insects were collected during the course of this study.

\section{Results}

When first observed, the Delta sp. was adding mud to the top left of the nest and the two S. cyanurum individuals were both perched on the wall approximately $10 \mathrm{~cm}$ from the nest (Figure 1a and 1b). An incomplete cell (clearly not yet provisioned) was apparent on the right-hand end of the nest (Figures 1 and 2). While busy on the nest, the Delta sp. was attacked by both $S$. cyanurum individuals, which proceeded to simultaneously dive-bomb and repeatedly mob her (Figure 1c-h). The Delta sp. exhibited defensive behaviour, trying to face the attackers with raised wings, periodically flying at one or other of them, and sometimes striking them in mid-air (Figure $1 \mathrm{i}$ and 1j). While the Delta sp. was thus preoccupied with one $S$. cyanurum individual, the other would sneak onto the nest. However, the Delta sp. would usually return quickly to the nest before the second individual was able to commence oviposition. On three occasions during my observation times, however, the Delta sp. left the nest for several minutes to collect mud, presumably from the banks of the river approximately $100 \mathrm{~m}$ away. During these periods when the Delta sp. was absent, both S. cyanurum individuals landed on the nest and one of them would proceed to oviposit (Figure 2). Only one individual was observed actually ovipositing at any given time, although the second individual would perch on the nest, often quite close to the ovipositing individual (Figure 2e).

The three instances of actual oviposition that were observed (at 12:35, 12:44 and 14:07; Figure 2), all lasted less than 2 min and were each terminated by the return of the Delta sp. who immediately attacked the intruder on her nest. In each instance (including the third instance which was approximately $1 \mathrm{~h} 30 \mathrm{~min}$ after the first observed instances), the $S$. cyanurum wasps targeted the same cell at the top left of the nest. Oviposition was achieved by first chewing a hole in the mud (or perhaps just moistening the mud as described by Móczár 1961; Figure 2a) and then turning around and inserting her ovipositor (Figure 2b). The S. cyanurum individual sometimes rotated around her ovipositor as she strained to get it through the mud wall (Figure 2c).

On her return to the nest, the Delta sp. proceeded to refill the hole made by the ovipositing $S$. cyanurum, but also built this part of the wall up (note the wet mud in Figure 2d). The Delta sp. was only concerned with repairing and building up this part of the nest during my observations, and was still attending to the same area on the nest when I returned approximately $1 \mathrm{~h} 30 \mathrm{~min}$ after the first observation period. The Delta sp. was never observed bringing provisions to the nest, despite the presence of an open (unprovisioned) cell on the nest.

\section{Discussion}

Several aspects of this attack are unusual. The simultaneous attack by two $S$. cyanurum individuals has not previously been reported. It is not clear if these were deliberately working together or competing for access to the nest. 
However, they did not display competitive behaviour when the Delta sp. was absent, and only one attempted to oviposit at any given time, sometimes with the second individual perched close by on the nest (Figure 2e). It was not possible to distinguish between the individuals, so it is not clear if both oviposited at different times, although this seems likely. Alternatively, the second individual may have been a male, although this would be extremely unusual in Hymenoptera (Brockmann \& Grafen 1989; Hamilton 1964). However, there are various groups of Sphecidae in which the males guard the nest during provisioning (reviewed by Brockmann \&
Grafen 1989), so it is not entirely inconceivable for a male cuckoo wasp to assist a female in gaining access to a nest. It is also not clear how beneficial the dual attack was in terms of achieving oviposition: although attacking simultaneously appeared to apply more pressure on the Delta sp., she was still able to prevent either of the intruders from accessing her nest for long enough to oviposit while she was present.

The brazen physical confrontation and harassing of the host are also unusual and have not previously been reported for this species. Móczár (1961) describes observations of
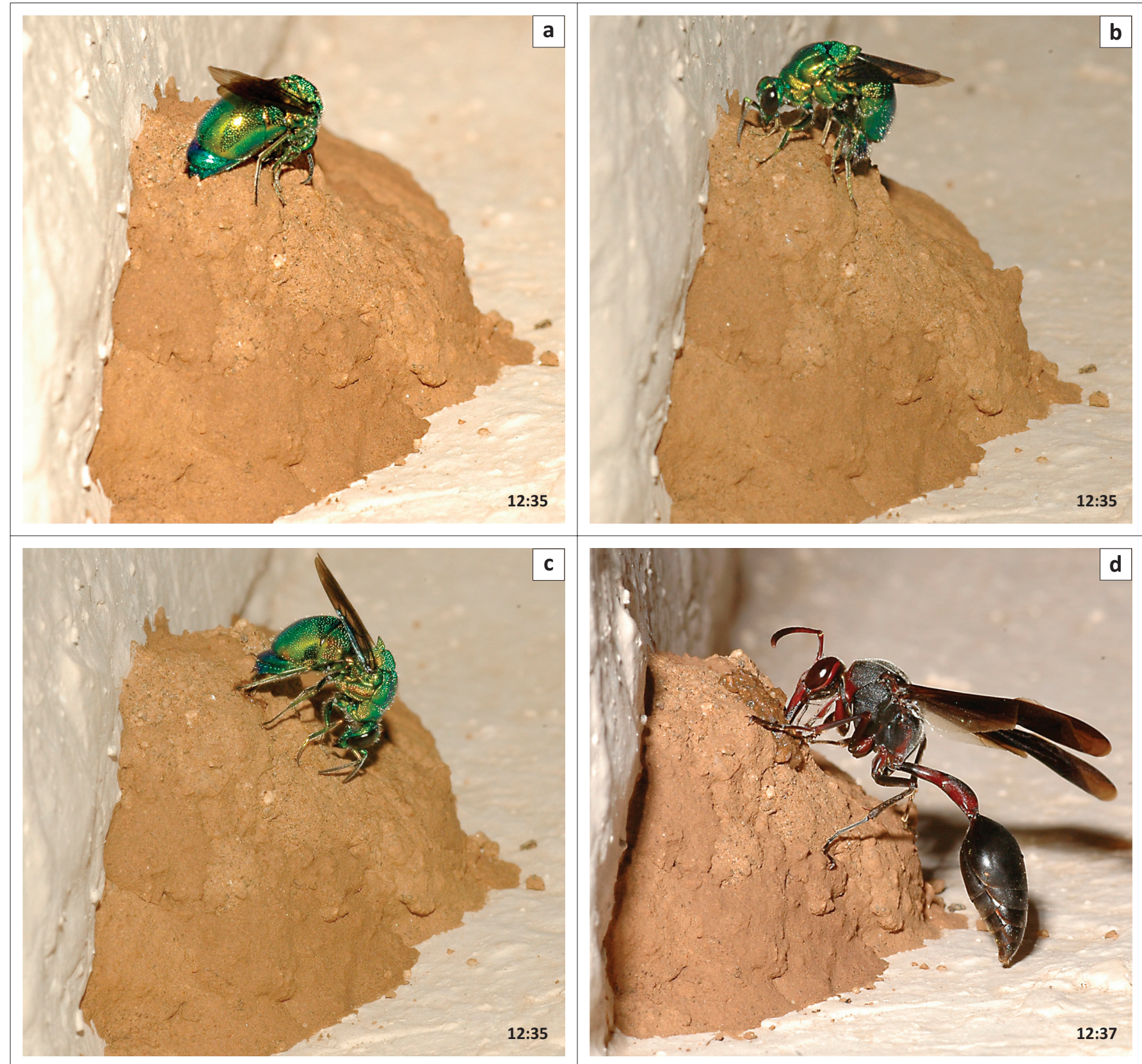

Source: Photos courtesy of the author, Adam Shuttleworth

FIGURE 2: Stilbum cyanurum wasps ovipositing into the Delta sp. nest. Photograph times are included to illustrate the sequence of oviposition instances. The S. cyanurum would first chew a hole in the mud (a), before turning around and inserting her ovipositor (b). While straining to penetrate the mud wall, the $S$. cyanurum would sometimes rotate around her ovipositor (b)-(c). Oviposition was always terminated by the return of the Delta sp., who would immediately chase the $S$. cyanurum off the nest and then repair the holes made by the ovipositing $S$. cyanurum wasps ([d], note the wet mud). Only one $S$. cyanurum was observed to oviposit at any given time, although the second individual was sometimes perched alongside on the nest ([e], the individual on the right is ovipositing). The $S$. cyanurum wasps were still ovipositing in the same part of the nest during the second observation period approximately 1.5 hours later ([f], note the additional layers of mud added to this part of the nest in the interim). 


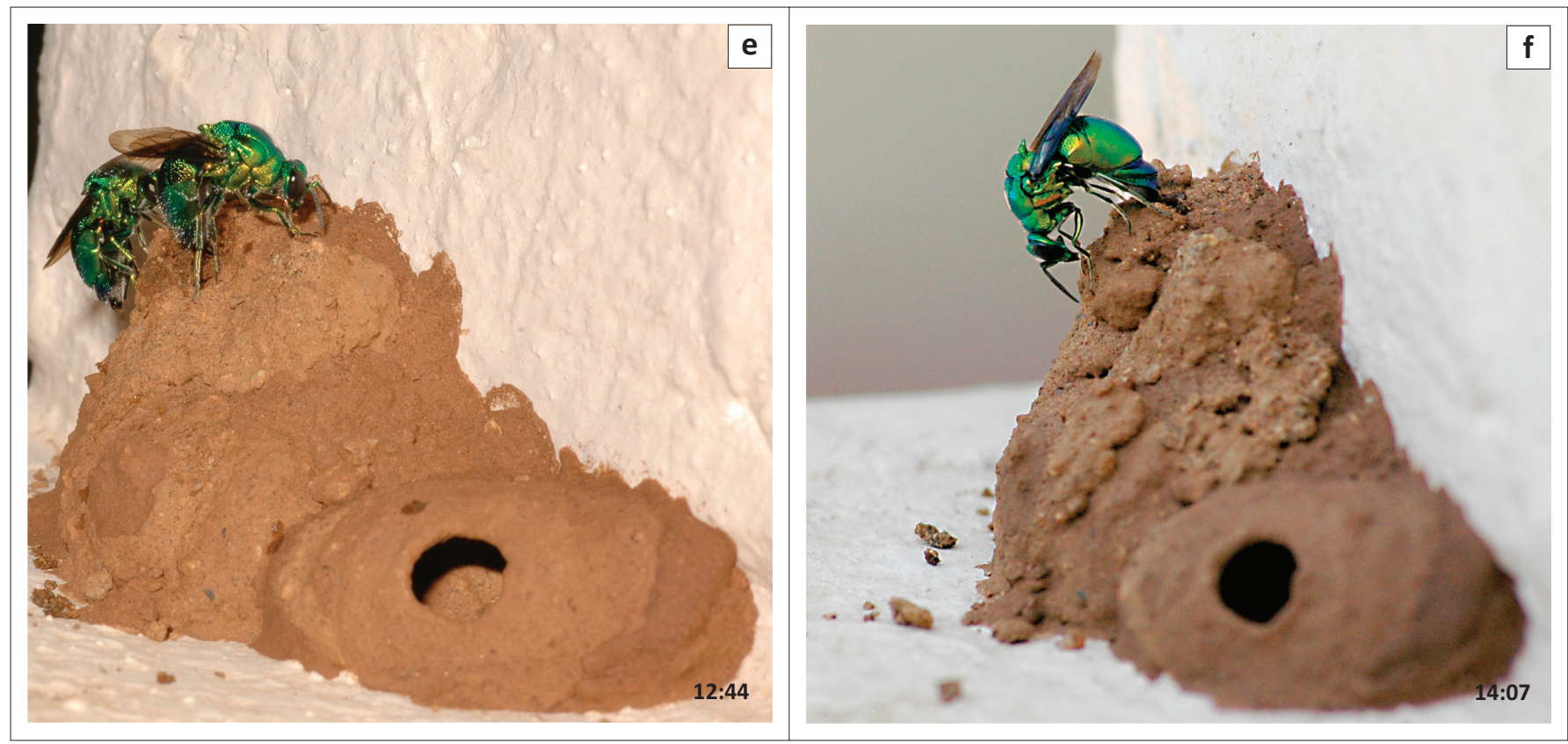

FIFURE 2 (Continues...): Stilbum cyanurum wasps ovipositing into the Delta sp. nest. Photograph times are included to illustrate the sequence of oviposition instances. The S. cyanurum would first chew a hole in the mud (a), before turning around and inserting her ovipositor (b). While straining to penetrate the mud wall, the S. cyanurum would sometimes rotate around her ovipositor (b)-(c). Oviposition was always terminated by the return of the Delta sp., who would immediately chase the S. cyanurum off the nest and then repair the holes made by the ovipositing $S$. cyanurum wasps ([d], note the wet mud). Only one $S$. cyanurum was observed to oviposit at any given time, although the second individual was sometimes perched alongside on the nest ([e], the individual on the right is ovipositing). The $S$. cyanurum wasps were still ovipositing in the same part of the nest during the second observation period approximately 1.5 hours later ([f], note the additional layers of mud added to this part of the nest in the interim).

oviposition by S. cyanurum in a Sceliphron destillatorium (Illiger) (Sphecidae) nest in Hungary. In this instance, the S. cyanurum inspected, but rejected, a nest that was partially constructed and contained a cell that was still in the process of being provisioned. She then selected a completed nest where the host had already departed. Matthews and Matthews (2009) describe observations in Australia of a different behaviour by an S. cyanurum ovipositing in a nest built by an Abispa ephippium (Fabricius) (Vespidae: Eumeninae) female, but which had been usurped by a female Pseudabispa paragioides (Meade-Waldo) (Vespidae: Eumeninae). Here, the $S$. cyanurum attacked the nest when the resident $P$. paragioides was away on a provisioning trip, but she was chased away by the returning host shortly after completing oviposition. The S. cyanurum then waited for the host to depart again before returning to refill her oviposition hole. In both these instances, the S. cyanurum avoided confrontation with the host. In the observations reported in this article, in contrast, the two S. cyanurum individuals were clearly trying to gain access to the nest despite the presence of the host (Delta sp.) on the nest. It is not clear why they did this, however, as they were never able to oviposit in her presence and still had to wait for her to leave the nest before being able to oviposit. One possibility is that they needed to attack the nest before the host had fully completed the construction of the nest. The nests of wasps in the genus Delta are typically completed by an outer envelope of mud of varying thickness (Gess \& Gess 2014). If the species of Delta observed here applies a particularly thick outer envelope, then it is possible that $S$. cyanurum needs to attack before the outer envelope has been completed.
Finally, the observation that the host Delta sp. actively repaired the oviposition holes of the S. cyanurum wasps is unusual. In the attack reported by Móczár (1961), the moistened mud around the oviposition site closed passively without active repair by either the $S$. cyanurum or the host. In contrast, the $S$. cyanurum observed by Matthews and Matthews (2009) actively repaired her own oviposition hole with mud chips. In the observations reported here, the host Delta sp. repeatedly repaired the holes made by the ovipositing S. cyanurum wasps (Figure $2 \mathrm{~d}$ ) and was solely occupied with this task, and the defence of her nest, during both observation periods.

\section{Conclusion}

The S. cyanurum attack described here, combined with the two previous reports for this species (Matthews \& Matthews 2009; Móczár 1961), reveal varied strategies across its range. This may either reflect local differences across the species range or plasticity with respect to the mode of attack for different hosts and their particular nests. It would be interesting to confirm if the behaviour described here is exhibited for attacks on other southern African host species, or if strategies are adapted to particular hosts and their specific nests.

\section{Acknowledgements}

The author would like to thank Denis Brothers for identification of the wasps and discussions of chrysidid behaviours, and the National Research Foundation of South Africa for funding this study. 


\section{Competing interests}

The author declares that he has no financial or personal relationships that may have inappropriately influenced him in writing this article.

\section{References}

Berland, L. \& Bernard, F., 1938, Hyménoptères vespiformes. 3, Cleptidae, Chrysidae, Trigonalidae, Faune de France 34, P. Lechevalier, Paris.

Brockmann, H.J. \& Grafen, A., 1989, 'Mate conflict and male behaviour in a solitary wasp, Trypoxylon (Trypargilum) politum (Hymenoptera: Sphecidae)', Anima Behaviour 37, 232-255. https://doi.org/10.1016/0003-3472(89)90113-9

Gess, S.K. \& Gess, F.W., 2014, Wasps and bees in southern Africa, SANBI Biodiversity ser. 24, South African National Biodiversity Institute, Pretoria.

Hamilton, W.D., 1964, 'The genetical evolution of social behaviour. II', Journal of Theoretical Biology 7, 17-52. https://doi.org/10.1016/0022-5193(64)90039-6

José, L., Carrillo, S. \& Caltagirone, L.E., 1970, 'Observations on the biology of Solierella peckhami, S. blaisdelli (Sphecidae), and two species of Chrysididae (Hymenoptera)',
Annals of the Entomological Society of America 63, 672-681. https://doi. org/10.1093/aesa/63.3.672

Kimsey, L.S. \&. Bohart, R.M., 1990, The chrysidid wasps of the world, Oxford University Press, Oxford.

Matthews, R.W. \& Matthews, J.R., 2009, 'Nesting behavior of Abispa ephippium (Fabricius) (Hymenoptera: Vespidae: Eumeninae): Extended parental care in an Australian mason wasp', Psyche 2009, 1-15. https://doi.org/10.1155/2009/851694

Móczár, L., 1961, 'On the habits of Stilbum cyanurum cyanurum Forst. (Hymenoptera, Chrysididae)', Annales Historico-naturales Musei Nationalis Hungarici 53, 463-466.

Strohm, E., Kroiss, J., Herzner, G., Laurien-Kehnen, C., Boland, W., Schreier, P. et al., 2008, 'A cuckoo in wolves' clothing? Chemical mimicry in a specialized cuckoo wasp of the European beewolf (Hymenoptera, Chrysididae and Crabronidae)', Frontiers in Zoology 5, 2. https://doi.org/10.1186/1742-9994-5-2

Veenendaal, R., 2012, 'De biologie van de goudwesp Holopyga generosa (Hymenoptera: Chrysididae)', Nedelandse Faunische Mededelingen 37, 39-43.

Weaving, A.J.S., 1995, 'A comparison of nesting success and nesting habits in some Afrotropical aculeate wasps, with particular reference to nest parasites (Hymenoptera: Sphecidae, Eumenidae)', Annals of the Cape Provincial Museums (Natural History) 19, 181-224.
(Nymenoptera: Sphecidae, Eumer

Winterhagen, P., 2015, 'Strategy for sneaking into a host's home: The cuckoo wasp Omalus biaccinctus (Hymenoptera: Chrysididae) inserts its eggs into living aphids that are the prey of its host', European Journal of Entomology 112, 557-559. https://doi.org/10.14411/eje.2015.064 